\title{
Mass propagation of pitaya (dragon fruit)
}

\author{
Ahmed A. ELOBEIDY
}

Department of Fruit Horticulture, Faculty of Agriculture, Cairo University, Giza, Egypt

elobeidy@hotmail.com

* Correspondence and reprints

Fruits, 2006, vol. 61, p. 313-319 (c) 2006 Cirad/EDP Sciences All rights reserved DOI: 10.1051/fruits:2006030 www.edpsciences.org/fruits

RESUMEN ESPAÑOL, p. 319

\section{Mass propagation of pitaya (dragon fruit).}

Abstract - Introduction. To facilitate establishment of pitaya (Hylocereus undatus) cultivations in new areas, factors affecting its propagation by cuttings and seeds were studied. Materials and methods. Firstly, cuttings of $(5,15$ and 25) $\mathrm{cm}$ length were tested in three substrates: peat moss $(\mathrm{pm})$, peat moss and sand mix (1:1) $(\mathrm{pm} / \mathrm{sa})$ and sand (sa). Indole-3-butyric acid (IBA) solutions were prepared at $[0,5,10$ or 15$] \mathrm{mM}$ dissolved in $70 \%$ ethanol. After the basal cuttings were dipped for $10 \mathrm{~s}$ in these IBA solutions, cuttings were planted in $(\mathrm{pm} / \mathrm{sa})$. After (1, 2 or 3 ) weeks, the cutting rooting, number and length of the developed roots were measured. Moreover, germination was tested at four temperatures [(16, 20, 24 and 28$\left.){ }^{\circ} \mathrm{C}\right]$ by placing seeds on wetted filter papers in Petri dishes. Light effect was tested at four white light intensities of $(0,500,1000$ or 2000$) \mathrm{lx}$. Seed viability was tested at $24{ }^{\circ} \mathrm{C}$ in darkness with 1000 seeds. The effect of (pm), (pm/sa) and (sa) was tested on germination and seedling growth. The percentage of germination, days to emergence and growth rate of seedlings were measured. Results and discussion. After two weeks, $25-\mathrm{cm}$ pitaya cuttings rooted successfully in the three substrates, but the number and length of the developed roots were affected by the type of substrate. A significant effect of cutting size on root initiation, and number and length of the developed roots was found. IBA consistently improved rooting percentage and root number and length. Overall, 5 -cm-long cuttings treated with IBA $(10 \mathrm{mM})$ could be efficient at propagating pitaya. The seed viability was $83 \%$. Germination, which varied between ( 71 and 83$) \%$ depending on the temperature, began after 6 days at $(24 \text { and } 28)^{\circ} \mathrm{C}$. Light intensity at (1000 or 2000) lx reduced seed germination. Potted seedlings grew successfully in the greenhouse.

Egypt / Hylocereus undatus / plant propagation / propagation by cuttings / sowing / germination / environmental factors

\section{Propagation en masse du pitaya.}

Résumé - Introduction. Pour faciliter l'établissement de la culture du pitaya (Hylocereus undatus) dans de nouveaux secteurs, des facteurs affectant sa propagation par boutures et semis ont été étudiés. Matériel et méthodes. Tout d'abord, des boutures de $(5,15$ et 25$) \mathrm{cm}$ de longueur ont été testées sur trois différents substrats : de la tourbe (to), un mélange (1:1) de tourbe et de sable (to/sa) et du sable (sa). Des solutions à (0, 5, 10 ou 15) $\mathrm{mM}$ d'acide indole-3-butyric (IBA) ont été préparées dans de l'éthanol à $70 \%$. Des boutures trempées $10 \mathrm{~s}$ dans de telles solutions d'IBA ont été plantées dans le substrat (to/sa). Après (1, 2 ou 3) semaines, le taux d'enracinement des boutures et le nombre et la longueur des racines développées ont été mesurés. Par ailleurs, la germination a été suivie à quatre températures $\left[(16,20,24\right.$ et 28$\left.){ }^{\circ} \mathrm{C}\right]$ en plaçant des graines en boîtes de Pétri sur du papier filtre mouillé. L'effet de la lumière a été évalué à quatre intensités de la lumière blanche $[(0,500,1000$ ou 2000) lx]. La viabilité des graines a été mesurée à $24^{\circ} \mathrm{C}$, à l'obscurité, sur 1000 graines. L'effet des substrats (to), (to/sa) et (sa) a été testé sur la germination et la croissance des plantules. Le taux de germination, l'émergence et la croissance des plantules ont été mesurés. Résultats et discussion. En deux semaines, les boutures de pitaya de $25 \mathrm{~cm}$ se sont enracinées avec succès dans les trois substrats, mais le nombre et la longueur des racines développées ont différé selon le substrat. Un effet significatif de la taille de la bouture sur la formation de racines et sur le nombre et la longueur des racines développées a été trouvé. Le traitement à l'IBA a amélioré le taux d'enracinement, ainsi que le nombre et la longueur des racines. De façon générale, les boutures de $5 \mathrm{~cm}$ traitées avec $10 \mathrm{mM}$ IBA pourraient être efficaces pour propager le pitaya. La viabilité des graines a été de $83 \%$. La germination, qui a varié de $(71$ à 83$) \%$ selon la température, a commencé après 6 jours à $(24$ et 28) ${ }^{\circ} \mathrm{C}$. Une intensité lumineuse de (1000 ou 2000) lx a freiné la germination des graines. Les jeunes plantes mises en pot se sont développées avec succès en serre.

Égypte / Hylocereus undatus / multiplication des plantes / bouturage / semis / germination / facteur du milieu 


\section{Introduction}

Pitaya (dragon fruit) (Hylocereus undatus) is a perennial, epiphytic, climbing cactus native to southern Mexico, Guatemala and Costa Rica [1, 2]. Its botanical name, Hylocereus, refers to both its habitat (hulos means "forest" in Greek) and the way in which it resists drought (the wax or cereus covering the stems) [3].

Not long ago, pitaya received significant attention for its potential as a new exotic fruit crop [4]. However, pitaya is considered a promising crop to be grown commercially in dry regions [5]. This species is found to have high water-use efficiency. One of the pitaya mechanisms to secure water requirement is developing aerial roots from the sides of the stem to collect water from the surroundings [6]. In addition, pitaya is characterized by a crassulacean acid metabolism (CAM) pathway that improves water-use efficiency [7].

Not only low moisture requirement, but also early ripening of the fruits increased interest in pitaya production [8]. Unlike the majority of fruit crops, pitaya plants begin to produce significant crops 2 to 3 years after planting and reach full production after 5 years $[9,10]$.

Pitaya fruit has red or pink thornless skins, while its juicy flesh can range from white to magenta. The skin is covered with bracts or scales. The small seeds are consumed with the fruit. The fruit can weigh up to $900 \mathrm{~g}$, but the average weight is between (350 and 450) g. Besides the nutritious value, pitaya fruits are rich in antioxidants [5].

Currently, pitaya is cultivated in 20 countries for its fruit [6], which is widely available in European fresh fruit markets [11, 12]. The quantities imported into the EU have increased strongly and steadily in recent years. Vietnam and Israel share the market, and a few extra batches arrive from Guatemala [3].

Overall, pitaya is a promising new crop [13], but growers should be cautious about the availability of explants for large-scale plantings. The species is propagated by cuttings or seeds. Propagation of pitaya by cut- tings is the most common method. Cutting may permit the production of plants with identical characteristics to the parent plant. Furthermore, cuttings reach production earlier [13]. Limiting the cutting material of pitaya when it is introduced as a new crop has generated interest in small cuttings for asexual propagation. On the other hand, pitaya sexual propagation by seeds is very important for breeding programs.

Our study was carried out to reveal the important factors affecting the propagation of pitaya by cuttings and seeds.

\section{Materials and methods}

Our research was conducted under controlled conditions in greenhouses or incubators.

\subsection{Cutting experiments}

Pitaya mother plants were established from cuttings introduced from the Jardin Exotique in Monaco (MC 98002 Monaco). Cuttings used in the experiments were taken from shoots of the mother plants grown in a greenhouse.

Cuttings were cured in a dry area at $24^{\circ} \mathrm{C}$ for 7 days before planting. Three types of substrate were tested: peat moss, peat moss and sand mix (1:1) and sand. Fifty pots of $25 \mathrm{~cm}$ in diameter were filled to about onethird full of each substrate. Cuttings of $25 \mathrm{~cm}$ length were inserted into a medium, with half this length under the surface. The pots were then filled up to two-thirds full with a type of substrate. The cuttings were firmed down. The pots were placed on a greenhouse bench. For each type of substrate, ten replicates were used, each of them consisting of five pots. The cuttings were watered every 5 days. Cuttings of $(5,15$ and 25) $\mathrm{cm}$ length were prepared either from an entire stem segment or from stem sections. The cuttings were cured, and then planted as above in the sand and peat moss potting mix (1:1). For each treatment (three types of cutting with three types of substrate), ten replicates were used, each of them consisting of five pots. 
Indole-3-butyric acid (IBA, Sigma, St. Louis, USA) solutions were prepared at [0 (distilled water control), 5, 10 or 15] mM. IBA was dissolved using $70 \%$ ethanol. The basal $1 \mathrm{~cm}$ of 5 -cm-long cured cuttings was dipped for $10 \mathrm{~s}$ in the IBA solutions. The excess solution on the cuttings was shaken off. The base of each cutting was dried in a current of air from a fan. The cuttings were then planted in the sand and peat moss potting mix (1:1). For each treatment, ten replicates were used, each of them consisting of five pots.

Cuttings were assessed after (1, 2 or 3 ) weeks for rooting, number and length of the developed roots.

\subsection{Seed experiments}

To extract seeds, fruits were sliced in half The fruit flesh was spooned out and mashed up in water. Seeds were separated from the pulp, dried at room temperature, then combined into one seed lot. They were kept at room temperature [(23 to 25$\left.)^{\circ} \mathrm{C}\right]$ for 2 days.

To test the temperature effect, treatments included four temperature regimes: (16, 20, 24 and $28{ }^{\circ} \mathrm{C}$. Germination was tested in a programed incubator. Seeds were germinated by placing them on wetted filter papers in 28-cm-diameter Petri dishes. For each treatment, five Petri dishes with 50 seeds each were used.

To test the light effect, 50 seeds were placed in each 28-cm-diameter Petri dish. Five Petri dishes were exposed in the incubator to one of the white light intensities of [0 (dark control), 500, 1000 and 2000] lx.

To determine their viability, seeds were placed on sheets of germination paper $(30 \mathrm{~cm} \times 38 \mathrm{~cm}$, Anchor Paper Co., St. Paul, $\mathrm{MN})$ moistened with deionized water. The sheets were rolled and placed in polyethylene bags. Germination was conducted in a programed incubator at $24^{\circ} \mathrm{C}$ in darkness. One thousands seeds were evaluated for their viability.

To test the substrate effect on germination and growth, three types of substrate were compared: peat moss, peat moss and sand mix (1:1) and sand. Each treatment was replicated three times. Each replicate was a styrofoam seed test with 60 cells, filled with a respective medium. The seeds were put one by one into the substrate, $5 \mathrm{~mm}$ deep, so that they were barely visible. Trials were placed on a greenhouse bench at $24^{\circ} \mathrm{C}$. Seedlings were watered every three days. The percentage of germination, days to emergence and growth rate of seedlings (length in $\mathrm{cm}$ ) were measured.

After 4 months, seedlings were potted into 20 -cm-diameter pots, which were placed on a greenhouse bench at $24^{\circ} \mathrm{C}$. They were watered every three days.

The experimental design was completely randomized. Analyses of variance were conducted using Costat, and means were separated by Duncan's Multiple Range Test at the $5 \%$ significance level.

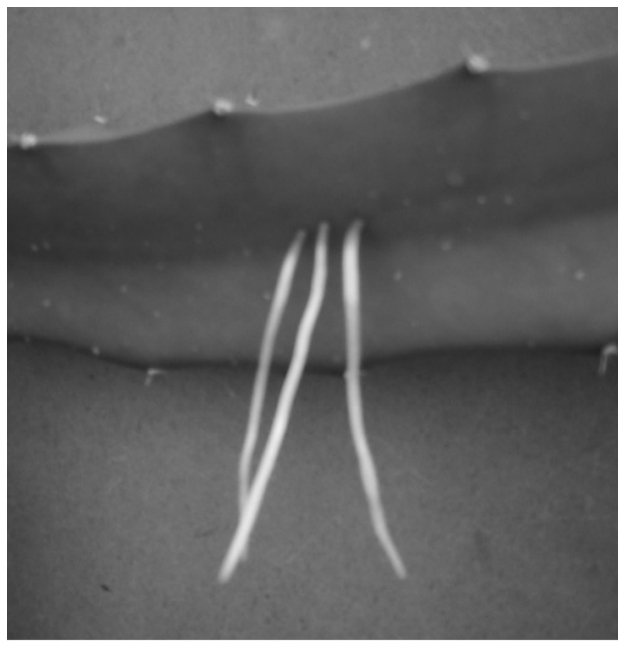

Figure 1.

Adventitious roots growing out of the side of the stem enable pitaya plants to be successfully grown from cuttings.
Table I.

Effect of substrate on the root number and length developed on pitaya cuttings of $25 \mathrm{~cm}$ length. All substrates made it possible to observe $100 \%$ of rooting.

\begin{tabular}{lcc}
\hline Substrate & Root number & $\begin{array}{c}\text { Root length } \\
(\mathrm{cm})\end{array}$ \\
\hline Peat moss & $43 \mathrm{a}$ & $6.2 \mathrm{c}$ \\
Peat moss and sand (1:1) & $38 \mathrm{~b}$ & $7.8 \mathrm{~b}$ \\
Sand & $14 \mathrm{c}$ & $8.2 \mathrm{a}$ \\
\hline $\begin{array}{l}\text { Means within the same column followed by a different letter differ significantly } \\
\text { (at } P=0.05) .\end{array}$
\end{tabular}


Figure 2.

Effect of cutting size on the root percentage, number and length in pitaya. For each parameter and each group considered, columns labeled with different letters are significantly different (at $P=$ 0.05).
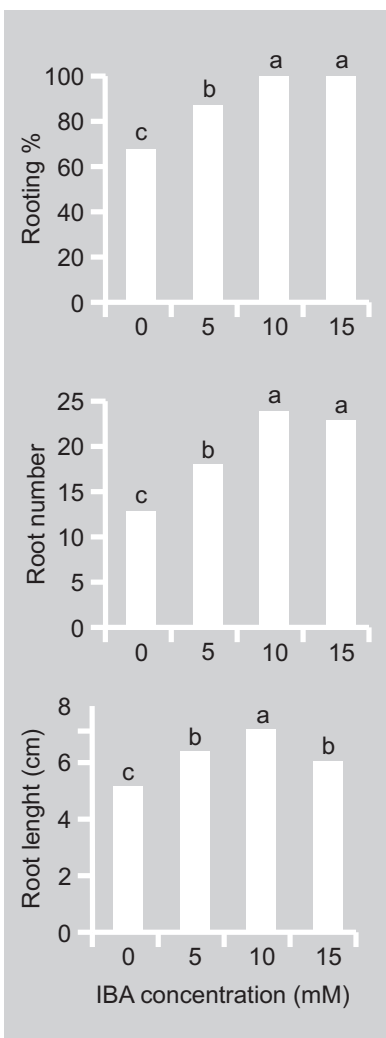

Figure 3.

Effect of indole-3-butyric acid (IBA) concentration on the root percentage, number and length in small cuttings of pitaya. For each parameter considered, columns labeled with the same letter are not significantly different (at $P=0.05$ ).

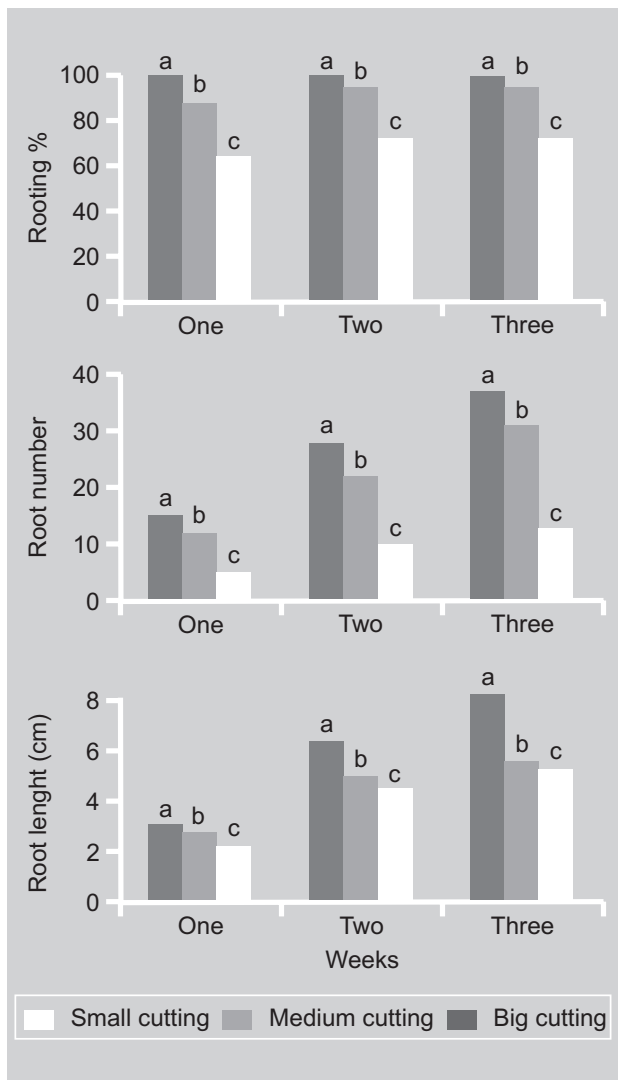

The results show a significant effect of cutting size on root initiation, and number and length of the developed roots. After 1 week, $100 \%$ of the big cuttings developed roots (figure 2). However, (87 and 65)\% of the medium and small cuttings, respectively, developed roots after the same time. The final rooting percentages in the medium and small cuttings were $(95$ and 72$) \%$, respectively. Furthermore, the number of roots developed on cuttings with different lengths differed dramatically (figure 2). Big cuttings made it possible to develop 15 roots after 1 week, and to reach 37 roots after 3 weeks. However, small cuttings developed only 13 roots after 3 weeks. Medium cuttings showed medium results compared with big and small cuttings. The differences among different sized pitaya cuttings in developing roots are most likely due to the differences in the amount of stored material necessary for growth and developing roots. Small cuttings have less material reserves than bigger ones. This may lead bigger cuttings to develop better roots. Rooting frequency was found to be significantly influenced by cutting size [14].

Root length increased linearly with time during the first three weeks (figure 2). However, root length was also affected by the cutting size. Big cuttings developed the longest roots and small cuttings developed the shortest ones.

Rooting of small sized cuttings was significantly improved by IBA treatment, which consistently acted on rooting percentage, root number and root length. Percentage of rooting increased from (74 to 87$) \%$ by IBA at $5 \mathrm{mM}$ and to $100 \%$ by IBA at (10 or 15) $\mathrm{mM}$ (figure 3).

All three IBA treatments resulted in more and longer roots formed by the treated cuttings than by the control ones (figure 3 ). However, the maximum root number and length, 24 and $7.2 \mathrm{~cm}$, respectively, were obtained with the 10-mM IBA treatment, while the minimum root number and length were recorded in cuttings dipped in distilled water (control treatment). Increasing the IBA concentration to $15 \mathrm{mM}$ neither further increased the percentage of rooting nor improved root quantity and quality above that achieved at the10-mM IBA concentration. 
IBA is the most important substance regulating root regeneration. It is the preferred auxin for the induction of root formation because it is much more potent than other auxins [15]. IBA can induce rooting and improve rooting quality [16, 17]. Root initiation is dependent on the presence of IBA, whether endogenous or artificially applied [18]. In addition, treatment with IBA stimulates more uniform root production on cuttings [16]. However, IBA concentration can significantly affect the process of rooting [17]. The effect of IBA on the rooting process may be due to its effect on cell wall turgidity, which accelerates cell division [16].

Overall, cuttings of $5 \mathrm{~cm}$ length, treated with $10 \mathrm{mM}$ IBA, could be an efficient method of propagating pitaya. Generally, the importance of cutting size is raised when cutting material is limited, especially with new crops or elite clones. However, if big cuttings of pitaya are superior, small cuttings may need to be used to satisfy large demand of plants. Improving propagation by small sized cuttings could make them ideal for propagation.

When cuttings are not available, seeds could be an alternative method of propagating pitaya. In addition, the genetic diversity of the seedlings could be utilized to improve clones. Pitaya seed viability was found to be $83 \%$. For many years, seed propagation was the principal method of producing new plants of many species. It was the least expensive means of propagation for producing a large number of new plants from a minimum of stock material. The main disadvantages of seed or sexual propagation are failing to produce plants true to variety (genetic diversity) and taking a longer time to produce fruits than from cuttings [16].

Pitaya seeds began to germinate after 6 days at (24 and 28$)^{\circ} \mathrm{C}$ (figure 4 ). However, seeds took (15 and 10) days before the onset of germination at (16 and 20$)^{\circ} \mathrm{C}$, respectively. The percentage of germinated seeds varied between 71 and 83 depending on the temperature (figure 4). The percentage of germination was much higher at $24^{\circ} \mathrm{C}$ than that at $28{ }^{\circ} \mathrm{C}$. However, the percentage of germination did not differ significantly at the temperatures (20 and 24$)^{\circ} \mathrm{C}$; seeds began to germinate earliest at $24^{\circ} \mathrm{C}$.
Each plant species has an optimum temperature range for germination. Many species have a wide temperature range for germination, but some are limited to a narrow range [16]. Pitaya seeds were found to germinate in a wide range of temperatures.

Low light intensity (500 lx) for (12 or 24) h.day ${ }^{-1}$ did not significantly affect germination of pitaya seeds (figure 5) but light intensities at (1000 or 2000) lx acted on seed germination. The period of illumination at high light intensity of $2000 \mathrm{~lx}$ significantly affected the percentage of germination. The percentage of germination dropped from (65 to 46)\% as the period of illumination increased from (12 to 24) h.day ${ }^{-1}$ at $2000 \mathrm{~lx}$. Light can stimulate or inhibit seed germination. This determines whether the seed should be sown on the surface of the growing medium or below the surface [17]. Generally, seed germination is affected by the intensity, spectral composition and periodicity of light [19].

After 18 days, the seedlings started to appear in the peat moss substrate (table II). However, the percentage of germination in that substrate was $77 \%$. In the [peat moss / sand] mix substrate, seedlings began to appear after 20 days, but the percentage of germination then reached $82 \%$. Seedlings in the sand began to appear after 29 days, with

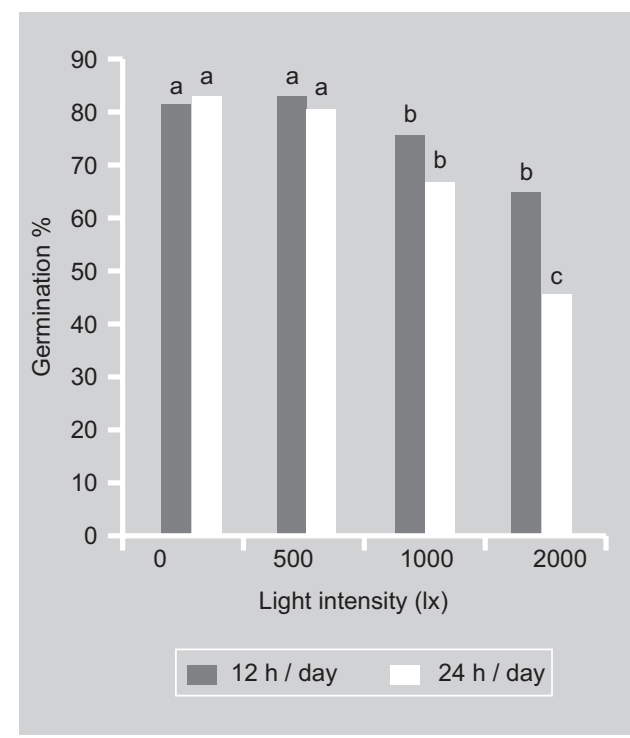

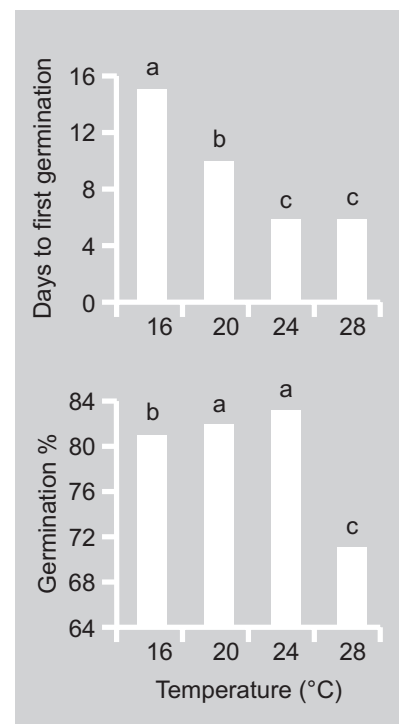

Figure 4.

Effect of temperature on the onset and on the percentage of germination for pitaya seeds. For each parameter considered, columns labeled with the same letter are not significantly different (at $P=$ 0.05).

Figure 5.

Effect of light intensity and illumination period on germination of pitaya seeds. Columns labeled with the same letter are not significantly different (at $P=0.05$ ). 
Table II.

Effect of substrate on the development of pitaya seedlings.

\begin{tabular}{lc|cc|}
\hline Substrate & \% Germination & $\begin{array}{c}\text { Day number before } \\
\text { emergence }\end{array}$ & $\begin{array}{c}\text { Growth rates } \\
\left(\mathrm{mm} \cdot \text { week }^{-1}\right)\end{array}$ \\
\hline Peat moss & $77 \mathrm{~b}$ & $18 \mathrm{c}$ & $1.5 \mathrm{a}$ \\
Peat moss and sand (1:1) & $82 \mathrm{a}$ & $20 \mathrm{~b}$ & $1.4 \mathrm{~b}$ \\
Sand & $76 \mathrm{~b}$ & $29 \mathrm{a}$ & $0.7 \mathrm{c}$
\end{tabular}

Means within the same column followed by a different letter differ significantly (at $P=0.05)$.

\section{Figure 6.}

Potted seedlings of pitaya grew successfully in the greenhouse.

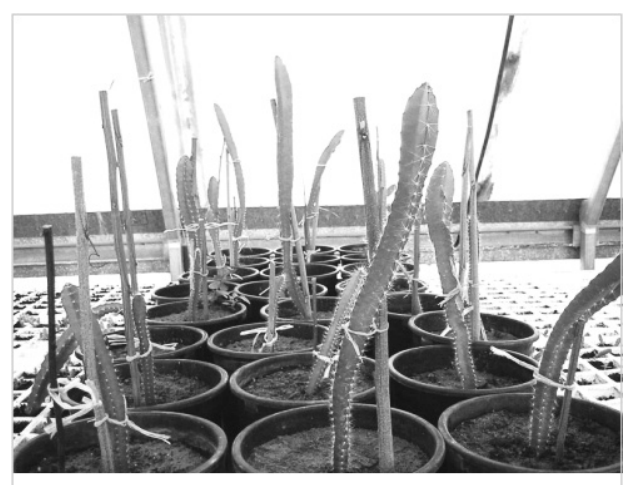

\section{Acknowledgement}

a germination percentage of $76 \%$. Generally, media used for germinating seed must have a high water-holding capacity, good drainage and good aeration [16].

The seedlings came up with two seed leaves (cotyledons). As the seedlings developed, an angular spiny stem grew in the central growing point between the two leaves. As the stem thickened and elongated, the cotyledons shriveled and shed.

The rate of growth during the second month after seeding was greater in the pure peat moss and mix substrate than in the pure sand (table II). There was a correlation between the growth rate and degree of emergence. Seedlings with the fastest growth rate resulted in the highest degree of emergence.

Potted seedlings grew successfully in the greenhouse (figure O). Stakes were needed to support the seedlings. crops, Hortic. Rev. 18 (1997) 291-320.
The author would like to thank Dr. JeanMarie Solichon, Director of the Jardin Exotique in Monaco, for supplying the plant material.

\section{Conclusion}

Large-scale pitaya plantation in a new area requires a huge amount of explants. Cuttings were found to be easy method of propagating pitaya. However, limiting cutting material may be considered an obstacle to producing explants on a large scale. As a result, the cutting size of pitaya may be a contributing factor to asexual propagation success. Rooting on small cuttings of pitaya was stimulated by IBA treatments. Small cuttings treated with IBA could be used effectively to multiply pitaya.

Seeds that could be used in pitaya breeding programs are generally available. Pitaya seed viability was found to be high. Germination and growth of pitaya seedlings were improved by defining the suitable substrate, temperature and light intensity.

\section{References}

[1] Mizrahi Y., Nerd A., Nobel P.S., Cacti as

[2] Zee F., Yen C., Nishina M., Pitaya (Dragon fruit, Strawberry pear), Fruits and Nuts, 9, Univ. Hawaii, Coll. Trop. Agric. Hum. Resour., Coop. Ext. Serv., USA, 2004.

[3] Le Bellec F., Vaillant F., Imbert E., Pitahaya (Hylocereus spp.): a new fruit crop, a market with a future, Fruits 61 (2006) 237-250.

[4] Lichtenzveig J., Abbo S., Nerd A., Tel-Zur N., Mizrahi Y., Cytology and mating systems in the climbing cacti Hylocereus and Selenicereus, Am. J. Bot. 87 (2000) 1058-1065.

[5] Vaillant F., Perez A., Davila I., Dornier M., Reynes M., Colorant and antioxidant properties of red-purple pitahaya (Hylocereus sp.), Fruits 60 (2005) 3-12.

[6] Nobel P., de la Barrera E., $\mathrm{CO}_{2}$ uptake by the cultivated hemi epiphytic cactus, Hylocereus undatus, Ann. Appl. Biol. 144 (2004) 1-8. 
[7] Cushman J.C., Crassulacean acid metabolism: recent advances and future opportunities, Funct. Plant Biol. 32 (2005) 375-380.

[8] Ebert G., Fischer G., Ludders P., Pitaya - a new fruit species from Colombia, Erwerbsobstbau 35 (1993) 49-52.

[9] Jacobs D., Pitaya (Hylocereus undatus), a potential new crop for Australia, Aust. New Crop Newsl. 29 (1999)16.3.

[10] Raveh E., Nerd A., Mizrahi Y., Responses of two hemi epiphytic fruit crop cacti to different degrees of shade, Sci. Hortic. 73 (1997) 151-164.

[11] Barbeau G., The red pitaya, a new exotic fruit, Wanatca Yearbook 17 (1993) 74-80.

[12] Weiss J., Scheinvar L., Mizrahi Y., Selenicereus megalanthus (the yellow pitaya), a climbing cactus from Colombia and Peru, Cactus Succul. J. 67 (1995) 280-283.

[13] Merten S., A review of Hylocereus production in the United States, J. Prof. Assoc. Cactus Dev. 5 (2003) 98-105.
[14] Browne R.D., Davidson C.G., Steeves T.A., Dunstan D.I., Rooting of proliferated dwarf shoot cuttings of jack pine (Pinus banksiana), Can. J. For. Res. 27 (1997) 97-101.

[15] Ludwig-Muller J., Indole-3-butyric acid in plant growth and development, J. Plant Growth Regul. 32 (2000) 219-230.

[16] Hartmann H.T., Kester D.E., Davies F.T. Jr., Geneve R.L., Plant propagation: principles and practices, Prentice Hall, Up. Saddle River, N.J., USA, 2002.

[17] Raven P., Evert R., Eichhorn S., Biology of Plants, Freeman WH and Co., N.Y., USA, 1999.

[18] Haissig B.E., Meristematic activity during adventitious root primordium development Influences of endogenous auxin and applied gibberellic acid, Plant Physiol. 49 (1972) 886-892.

[19] Fenner M., Seeds - The ecology of regeneration in plant communities, CAB Int., Wallingford, UK,1992.

\section{Propagación en masa de la pitaja.}

Resumen - Introducción. Con el fin de facilitar el establecimiento de la cultura de la pitaja (Hylocereus undatus) en sectores nuevos, se estudiaron los factores que afectan su propagación por esquejes y por siembra. Material y métodos. Antes de todo se testaron esquejes de $(5,15$ y 25) cm de longitud en tres sustratos diferentes: turba (tu), una mezcla (1:1) de turba y de arena (tu/ar) y arena (ar). Se prepararon soluciones con (0, 5, 10 ó 15) mM de ácido indole-3-butyric (IBA) en etanol de 70\%. Se plantaron en el sustrato (tu/ar) esquejes previamente sumergidos durante $10 \mathrm{~s}$ en estas soluciones de IBA. Tras (1, 2 o 3) semanas, se midió la tasa de enraizamiento de los esquejes así como el número y la longitud de las raíces desarrolladas. Por otro lado, se hizo un seguimiento de la germinación bajo cuatro temperaturas [(16, 20,24 y 28$\left.)^{\circ} \mathrm{C}\right]$, colocando semillas en cápsulas de Petri en papel filtro mojado. Se evaluó el efecto de la luz bajo cuatro intensidades de la luz blanca $[(0,500,1000$ ó 2000) lx]. Se midió la viabilidad de las semillas a $24{ }^{\circ} \mathrm{C}$, en la oscuridad, en 1000 semillas. Se testó el efecto de los sustratos (tu), (tu/ar) y (ar) en la germinación y en el crecimiento de las plántulas. Se midieron la tasa de germinación, el brote y el crecimiento de las plántulas. Resultados y discusión. En un tiempo de dos semanas, los esquejes de pitaja se enraizaron exitosamente en los tres sustratos, mientras que el número y la longitud de las raíces desarrolladas variaron de acuerdo con el sustrato. Se halló un efecto significativo del tamaño del esqueje en la formación de las raíces y en el número y en la longitud de las raíces desarrolladas. El tratamiento a base de IBA mejoró la tasa de enraizamiento, así como el número y la longitud de las raíces. De modo general, los esquejes de $5 \mathrm{~cm}$ tratados con $10 \mathrm{mM}$ IBA podrían ser eficaces para propagar la pitaja. La viabilidad de las semillas fue de un 83\%. La germinación, que varió entre (71 y 83)\% de acuerdo con la temperatura, comenzó después de 6 días bajo $\left(24\right.$ y 28) ${ }^{\circ} \mathrm{C}$. Una intensidad luminosa de (1000 ó 2000) lx frenó la germinación de las semillas. Las jóvenes plantas trasplantadas en macetas se desarrollaron exitosamente en invernadero.

Egipto / Hylocereus undatus / propagación de plantas / esquejado / siembra / germinación / factores ambientales 